\title{
INFLUENCE OF GROWTH CONDITIONS ON BIOFILM FORMATION OF Listeria monocytogenes
}

\author{
Ružica M. Tomičić ${ }^{1}$, Ivana S. Čabarkapa ${ }^{2}$, Đuro M. Vukmirović ${ }^{2}$, Jovanka D. Lević ${ }^{2}$ Zorica M. \\ Tomičić $^{2}$ \\ ${ }^{1}$ Faculty of Technology, University of Novi Sad, Bulevar cara Lazara 1, 21000 Novi Sad, Serbia \\ ${ }^{2}$ Institute of Food Technology, University of Novi Sad, Bulevar cara Lazara 1, 21000 Novi Sad, Serbia
}

*Corresponding author:
E-mail address: ruzica.tomicic@yahoo.com; ruzica.tomicic@uns.ac.rs

\begin{abstract}
Listeria monocytogenes is ubiquitous in nature and a major concern for the food industry, since it is the causal agent of the serious foodborne illness listeriosis. This organism can be introduced through many routes to food-processing environments and may become established on food-processing equipment. Subsequently, food products may become contaminated during processing. In addition, the bacterium can grow at refrigeration temperatures. Biofilms are regarded as important with respect to the survival and growth of microorganisms in the food industry. Microorganisms growing in biofilms are protected against cleaning and disinfection and are difficult to eradicate. L. monocytogenes may grow in biofilms that protect them against environmental stress and can be isolated from surfaces after cleaning and disinfection. In this study, a total of eight $L$. monocytogenes strains isolated from the meat industry and one reference strain L. monocytogenes ATCC 19111 were studied for their capability to form a biofilm. The biofilm forming behavior of nine $L$. monocytogenes strains was determined in two different media, Tryptone soya yeast extract broth (TSYEB) or Brain-heart infusion broth (BHI), at temperatures $7^{\circ} \mathrm{C}, 25^{\circ} \mathrm{C}, 37^{\circ} \mathrm{C}, 42^{\circ} \mathrm{C}$ for 5 days. The method used to assess biofilm formation was crystal violet staining. All strains were able to form biofilm, but the growth condition affected the levels formed. The lowest biofilm formation was observed at $7{ }^{\circ} \mathrm{C}$. Further, the most effective medium in promoting biofilm production by the $L$. monocytogenes isolates from meat was BHI medium while for reference strain L. monocytogenes ATCC 19111 it was TSYEB. Incubation temperature was the most significant factor influencing the biofilm production levels, and also the type of used nutritive medium was important factor.
\end{abstract}

Key words: biofilm formation, Listeria monocytogenes, growth medium, temperature

\section{INTRODUCTION}

Listeria monocytogenes is a ubiquitous gram-positive facultative intracellular bacterial pathogen which provokes listeriosis, a severe disease with high hospitalization and mortality rates, with the consumption of contaminated food being the principle mode of its transmission to humans. Due to the ubiquitous nature and hardy growth characteristics of this bacterium, L. monocytogenes is able to contaminate and thrive in the food-processing environment (Kadam et al., 2013). In particular, the psy- chrotrophic nature of $L$. monocytogenes allows replication in refrigerated, ready-toeat food products that have been contaminated during processing and packaging. Consequently, L. monocytogenes is frequently associated with food-borne disease outbreaks that are characterized by widespread distribution and relatively high mortality rates (Donlan and Costerton, 2002; Donnelly, 2001).

This organism possesses the ability to adhere to and colonizes on abiotic surfaces 
to form biofilms (Yousef and Carlstrom, 2003). Once bacteria adhere to solid surfaces and form biofilms, they became more resistant to cleaning and sanitation treatment, and cells detaching from the biofim can further turn into the source of persistent contamination (Hood and Zottola, 1997; Donlan and Costerton, 2002). In the food industries, biofilm accumulations have been found on walls, floors, drains, rubber, conveyor belts, processing equipment, which is more resistant to disinfectants and sanitizing agents than planktonic cells (Milovanov et al., 2015; Moltz and Martin, 2005).

L. monocytogenes is found in many types of food products, especially raw and ready-to-eat products such as milk, meat, cheese, and flour (Šarić et al., 2014). Postprocess contamination of a food product with $L$. monocytogenes is an ongoing problem because the pathogen can survive and grow at refrigeration temperatures (as low as $-1.5^{\circ} \mathrm{C}$ ) and in environments with reduced water activity (Silva et al., 2008). This bacterium tolerates freezing and high salt concentrations (up to $30 \%$ ) and grows at $\mathrm{pH}$ values below 5.0 (Han and Linton, 2004). Particularly in processing and storage, long term storage at various temperatures plays a critical role in determining the density of biofilm formation in the food products.

The consequences of Listeria contaminated foods may not only present detrimental health effect but also implies economic losses as a result of biofouling, a term describing the biofilm attaching to a surface that will spoil the food products and equipment (Harvey et al., 2007).

The factors governing the biofilm formation of bacteria to surfaces are still not well understood. Therefore, the aim of this study was to determine the biofilm forming behavior of nine $L$. monocytogenes strains in two different media such as Tryptone soya yeast extract broth (TSYEB) or Brainheart infusion broth $(\mathrm{BHI})$ at temperatures $7{ }^{\circ} \mathrm{C}, 25^{\circ} \mathrm{C}, 37^{\circ} \mathrm{C}, 42^{\circ} \mathrm{C}$ during 5 days.

\section{MATERIAL AND METHODS}

\section{Strains and growth conditions}

A total of 9 L. monocytogenes strains were used in this study. Tests were performed with 8 isolates of L. monocytogenes (Lm1Lm8) isolated from meet processing industry. L. monocytogenes ATCC 19111 (lyophilized cultures of microorganisms, American Type Culture Collection, KwikstickTM set, MicroBioLogics) was used as a reference strain. The stock cultures were stored at $-80{ }^{\circ} \mathrm{C}$ in Tryptone Soya Broth supplemented with glycerol (15\%). These strains were revitalized from frozen stocks by cultivation on Nutrient Agar (NA) plates and incubated 2 days at $37^{\circ} \mathrm{C}$ before performing the biofilm formation assays.

\section{Biofilm formation assay}

Biofilm formation assays were performed as previously described by Mowat et al. (2007) with a few modifications. Prior to testing, strains were grown on NA plates at $37^{\circ} \mathrm{C}$ for $48 \mathrm{~h}$. After the incubation, a loopful of actively growing cells was suspended in the appropriate medium TSYEB (HiMedia) or BHI (HiMedia) and adjusted to 0.5 McFarland standard turbidity to achieve a final cell concentration of $1 \times 10^{7} \mathrm{cells} / \mathrm{ml}$. The assay was initiated by the addition of $200 \mu \mathrm{l}$ cell suspensions into 96-well polystyrene microtiter plate, which were than incubated at four temperatures $7{ }^{\circ} \mathrm{C}, 25^{\circ} \mathrm{C}, 37^{\circ} \mathrm{C}, 42^{\circ} \mathrm{C}$ for 5 days. In all experiments a positive (assay medium with bacterial strains) and a negative control (growth medium without bacterial strains) were included.

After incubation period, non-adherent cells were removed by washing three times with $250 \mu \mathrm{l}$ sterile distilled water. After $10 \mathrm{~min}$ drying with hair drier, the bacterial cells in the wells were stained with $100 \mu \mathrm{l} 0.5 \%$ crystal violet and left on bench for $20 \mathrm{~min}$. The redundant crystal violet was removed by inverting the plates and the wells were washed three times with sterile distilled water and dried for another $10 \mathrm{~min}$ with hair drier. After adding $100 \mu \mathrm{l}$ of $33 \%$ acetic acid into each well, the plates were shaken for $3 \mathrm{~min}$ to release the dye from the cells. The amount of adhered cells, i.e. the concentration of the released crystal violet was determined by measuring the optical density at $630 \mathrm{~nm}\left(\mathrm{OD}_{630}\right)$ using a microplate reader (ChemWel, Awareness Technology). 


\section{Statistical analysis}

All quantitative data are presented as mean values with error represented by standard deviation (SD) from two independent experiments. The resulting data were analyzed using Anova: Two-Factor with replication in Microsoft Excel. A P-value of $<0.05$ was considered as statistically significant.

\section{RESULTS AND DISCUSSION}

It is commonly accepted that cells in biofilms are more resistant to biocides, antibiotics, antibodies, and surfactants than are planktonic cells. Therefore, knowledge on biofilm capacity of foodborne pathogens is of major importance for the food industry, in order to define the most effective cleaning and disinfection strategies. Several L. monocytogenes isolates from meat were studied concerning their ability to produce biofilms at different growth conditions. The focus was on growth medium and temperatures (Moltz and Martin, 2005).

Evaluation of biofilm formation by L. monocytogenes in this study revealed that these bacteria possess a capacity for biofilm formation on polystyrene surfaces, in terms of the number of biofilm producing strains. However, it was noted that $L$. monocytogenes ATCC 19111 and Lm 1 were showed a much greater propensity for biofim formation in comparison with other strains (Figure 1 and Figure 2). This intra-species variation by $L$. monocytogenes in its adherence to plastic surfaces has been reported previously (Chavant et al., 2002; Djordjević et al., 2002; Stepanović et al., 2004). Such findings undoubtedly reflect inherent physiological differences between strains, and could have significance with respect to pathogenic potential.

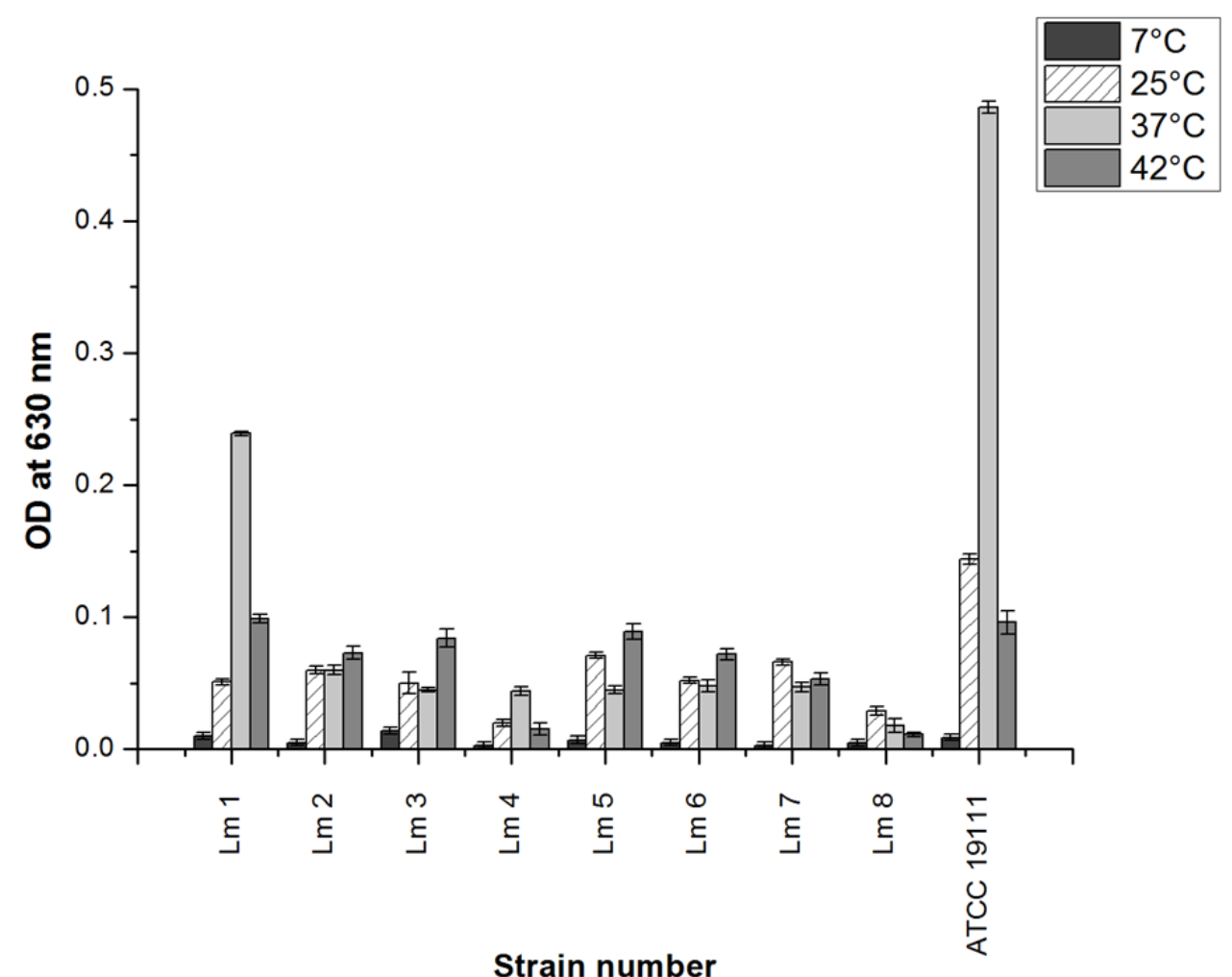

Figure 1. Biofilm formation by nine $L$. monocytogenes strains grown in TSYEB medium. Strains were incubated at $7{ }^{\circ} \mathrm{C}, 25^{\circ} \mathrm{C}, 37^{\circ} \mathrm{C}, 42^{\circ} \mathrm{C}$ for 5 days. Each bar represents the mean value of the optical density $(\mathrm{OD}) \pm$ standard deviation (SD). The experiments were performed with eight independent replicates 
Bacteria can grow over a wide range of temperatures and because adherence precedes growth, it is not suprising to find that biofilm formation also occur at wide temperature range. The influence of temperature on the ability of $L$. monocytogenes isolates to form biofilms has been previously reported (Norwood and Gilmour, 2001; Chavant et al., 2002; Di Bonaventura et al., 2008; Smoot and Pierson, 1998). Chavant et al. (2002) showed that L. monocytogenes LO28 colonized a polytetrafluoroethylene (PTFE) surface at $37{ }^{\circ} \mathrm{C}$, but not at $8{ }^{\circ} \mathrm{C}$. Di Bonaventura et al. (2008) also demonstrated that biofilm production on polystyrene surfaces by 44 different isolates of $L$. monocytogenes was significantly higher at $37^{\circ} \mathrm{C}$ than at $4^{\circ} \mathrm{C}$. Norwood and Gilmour (2001), however, reported two L. monocytogenes isolates that adhered equally at $4^{\circ} \mathrm{C}$ and $30^{\circ} \mathrm{C}$. In agreement with previous studies, we demonstrated that the biofilm formation of $L$. monocytogenes strains was significantly stimulated at 25
${ }^{\circ} \mathrm{C}, 37^{\circ} \mathrm{C}$ and $42{ }^{\circ} \mathrm{C}$ in comparison to the lowest incubation temperature $7{ }^{\circ} \mathrm{C}(\mathrm{P}<$ 0.05). On the other hand, the results of the evaluation of biofilm formation on polystyrene surfaces by $L$. monocytogenes strains cultivated in two different media revealed that all tested strains produced biofilm in suitable medium. As shown in Figure 1 and Figure 2, the nutrient content of the medium significantly influenced the quantity of biofilm produced by tested bacteria $(P<0.05)$. The most effective medium in promoting biofilm production by the $L$. monocytogenes isolates from meat was $\mathrm{BHI}$ medium. On the contrary, statistical analysis showed that reference strain L. monocytogenes ATCC 19111 had a greater ability to form biofilm in TSYEB medium $(\mathrm{P}<0.05)$. BHI broth has been extensively used to study the biofilm formation capabilities of $L$. monocytogenes (Stepanović et al., 2004), and reported best biofilm formation of $L$. monocytogenes in $\mathrm{BHI}$ broth than other media studied (Kadam et al., 2013).

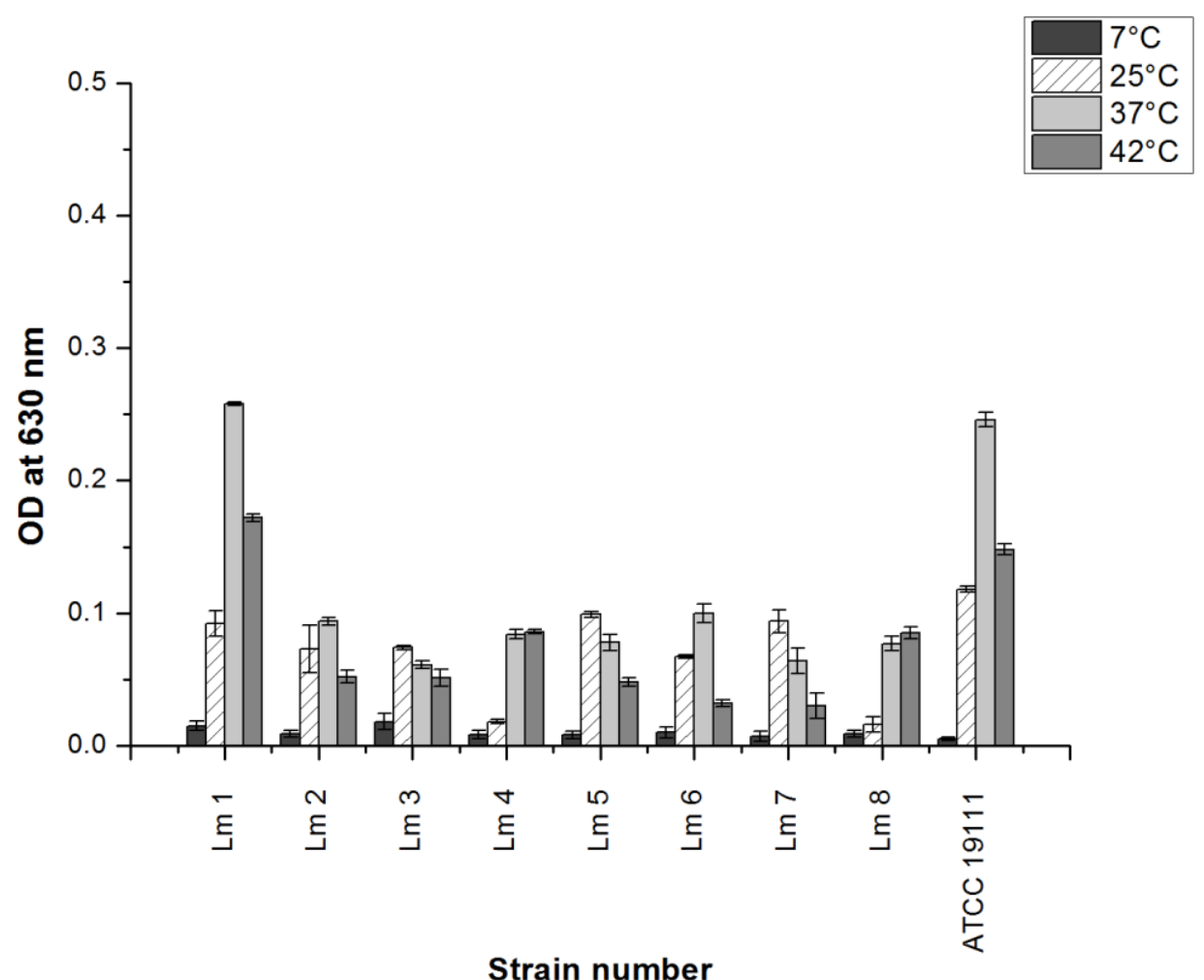

Figure 2. Biofilm formation by nine L. monocytogenes strains grown in BHI medium. Strains were incubated at $7{ }^{\circ} \mathrm{C}, 25^{\circ} \mathrm{C}, 37^{\circ} \mathrm{C}, 42^{\circ} \mathrm{C}$ for 5 days. Each bar represents the mean value of the optical density $(O D) \pm$ standard deviation (SD). The experiments were performed with eight independent replicates 


\section{CONCLUSIONS}

In conclusion, the incubation temperature was the most significant factor influencing the biofilm production levels. As we showed that $L$. monocytogenes strains were able to form biofilm at temperatures between $7{ }^{\circ} \mathrm{C}$ and $37^{\circ} \mathrm{C}$, a typical temperature used in the food industry during processing and storing, which suggests an increase in the likelihood of cross-contamination. For these reasons, our results could have a practical application to face the hygienic and sanitary issues raised by the adhesion in food industry by L. monocytogenes and indicate the importance of temperature as a factor. Furthermore, more information about biofilm formation characteristics of $L$. monocytogenes on food contact materials other than polystyrene with representative nutrient conditions will help to optimize strategies to control this biofilm-forming pathogen.

\section{ACKNOWLEDGEMENTS}

This paper is a result of the research within the project III46012 "Istraživanje savremenih biotehnoloških postupaka u proizvodnji hrane za životinje u cilju povećanja konkurentnosti, kvaliteta i bezbednosti hrane za životinje (Study of modern biotechnological methods in the production of animal feed in order to increase competitiveness, quality and safety of the feed)", financed by the Ministry of Science and Technological Development, Republic of Serbia.

\section{REFERENCES}

1. Chavant, P., Martinie, B., Meylheuc, T., BellonFontaine, M., Hebraud, M. (2002). Listeria monocytogenes LO28: Surface physic-chemical properties and ability to form biofilms at different temperatures and growth phases. Applied and Environmental Microbiology, 68, 728737.

2. Di Bonaventura, G., Piccolomin, R., Paludi, D., D'Orio, V., Vergara, A., Conter, M., lanieri, A. (2008). Influence of temperature on biofilm formation by Listeria monocytogenes on various food-contact surfaces: relationship with motility and cell surface hydrophobicity. Journal of Applied Microbiology, 104, 1552-1561.

3. Djordjevic, D., Wiedmann, M., McLands-borough, L.A. (2002). Microtiter plate assay for assessment of Listeria monocytogenes biofilm formation. Applied and Environmental Microbiology, 68, 2950-2958.

4. Donlan, R. M., Costerton, J.W. (2002). Biofilms: Survival mechanisms of clinically relevant micro-organisms. Clinical Microbiology Reviews, 15 (2), 167-193.

5. Donnelly, C.W. (2001). Listeria monocytogenes: a continuing challenge. Nutrition Reviews, 59, 183-194.

6. Han, Y., Linton, R.H. (2004). Fate of Escherichia coli O157:H7 and Listeria monocytogenes in strawberry juice and acidified media at different $\mathrm{pH}$ values and temperatures. Journal of Food Protection, 11, 2368-2626.

7. Harvey, J., Keenan, K.P., Gilmour, A. (2007). Assessing biofilm formation by Listeria monocytogenes strains. Food Microbiology, 24, 380392.

8. Hood, S. K., Zottola, E.A. (1997). Adherence to stainless steel by foodborne microorganisms during growth in model food systems. International Journal of Food Microbiology, 37, 145153.

9. Kadam, S.R., den Besten, H.M.W., van der Veen, S., Zwietering, M.H., Moezelaar, R., Abee, T. (2013). Diversity assessment of Listeria monocytogenes biofilm formation: Impact of growth condition, serotype and strain origin. International Journal of Food Microbiology, 165, 259-264.

10. Milanov, D., Velhner, M., Karabasil, N., Čabarkapa, I., Suvajdžić Lj. (2015). Epidemiological significance of Salmonella enteric serovar Montevideo and the potential role of feed for their entry into the food chain. Food and Feed Research, 42 (2), 155-162.

11. Moltz, A.G., Martin S.E. (2005). Formation of biofilms by Listeria monocytogenes under various growth conditions. Journal of Food Protection, 68 (1), 92-97.

12. Mowat, E., Butcher, J., Lang, S., Williams, C., Ramage, G. (2007). Development of a simple model for studying the effects of antifungal agents on multicellular communities of Aspergillus fumigatus. Journal of Medical Microbiology, 56, 1205-1212.

13. Norwood, D.E., Gilmour, A. (2001). The differrential adherence capabilities of two Listeria monocytogenes strains in monoculture and multispecies biofilms as a function of temperature. Letters in Applied Microbiology, 33, 320324.

14. Šarić, Lj., Šarić, B., Kravić, S., Plavšić, D., Milovanović, I., Gubić, J., Nedeljković, N. (2014). Antibacterial activity of Domestic Balkan donkey milk toward Listeria monocytogenes and Staphylococcus aureus. Food and Feed Research, 41 (1), 47-54.

15. Silva, S., Teixeira, P., Oliveira, R., Azeredo, J. (2008). Adhesion to and viability of Listeria monocytogenes on food contact surfaces. Journal of Food Protection, 71, 1379-1385.

16. Smoot, L.M., Pierson, M.D. (1998). Effect of environmental stress on the ability of Listeria monocytogenes Scott A to attach to food con- 
tact surfaces. Journal of Food Protection, 61, 1293-1298.

17. Stepanović, S., Ćirković, I., Ranin, L., ŠvabićVlahhović, M. (2004). Biofilm formation by Salmonella spp. and Listeria monocytogenes on plastic surface. Letters in Applied Microbiology, 38, 428-432.

18. Yousef, A.E., Carlstrom, C. (2003). Listeria monocytogenes in Food Microbiology. John Wiley\&Sons, Inc., Hoboken, NJ, pp. 138-139.

\section{УТИЦАЈ ФАКТОРА СРЕДИНЕ НА ФОРМИРАҢЕ БИОФИЛМА Listeria monocytogenes}

Ружица М. Томичић*1, Ивана С. Чабаркапа ${ }^{2}$, Ђуро М. Вукмировић ${ }^{2}$, Јованка Д. Левић², Зорица М. Томичић ${ }^{2}$

${ }^{1}$ Технолошки фракултет, Универзитет у Новом Саду, Булевар цара Лазара 1, 21000 Нови Сад, Србија

${ }^{2}$ Научни институт за прехрамбене технологије у Новом Саду, Универзитет у Новом Саду, Булевар цара Лазара 1, 21000 Нови Сад, Србија

Сажетак: Listeria monocytogenes је свеприсутна у природи и велики проблем у прехрамбеној индустрији, с обзиром да је узрочник листериозе, озбиљне болести изазване храном. Постоје многи путеви којим се овај микроорганизам може унети у фабричко окружење. Способност размножавања овог микроорганизма на температури складиштења $\left(+4{ }^{\circ} \mathrm{C}\right)$ представља велики проблем у прехрамбеној индустрији. Биофилмови се сматрају важним у смислу опстанка и развоја микроорганизама који их штите од деловања средстава за дезинфекцију. Циљ овог рада је био да се испита способност формирања биофилма осам сојева L. monocytogenes изолованих из меса и једног референтног соја L. monocytogenes ATCC 19111 у два различита медија Tryptone soya yeast extract broth (TSYEB) и Brain-heart infusion broth (BHI) на температурама $7^{\circ} \mathrm{C}, 25^{\circ} \mathrm{C}, 37^{\circ} \mathrm{C}, 42^{\circ} \mathrm{C}$ током 5 дана. Метод коришћен за процену способности формирања биофилма је кристал виолет тест. Резултати истраживања су показали да је најмања способност формирања биофилма сојева L. monocytogenes примећена на температури $7{ }^{\circ} \mathrm{C}$. Поред тога, најефикаснији медијум који је утицао на формирање биофрилма сојева изолованих из меса је ВНІ док је за референтни сој TSYEB.

Кључне речи: формирање биофилма, Listeria monocytogenes, медијум, температура

Received: 10 March 2016

Accepted: 30 May 2016 